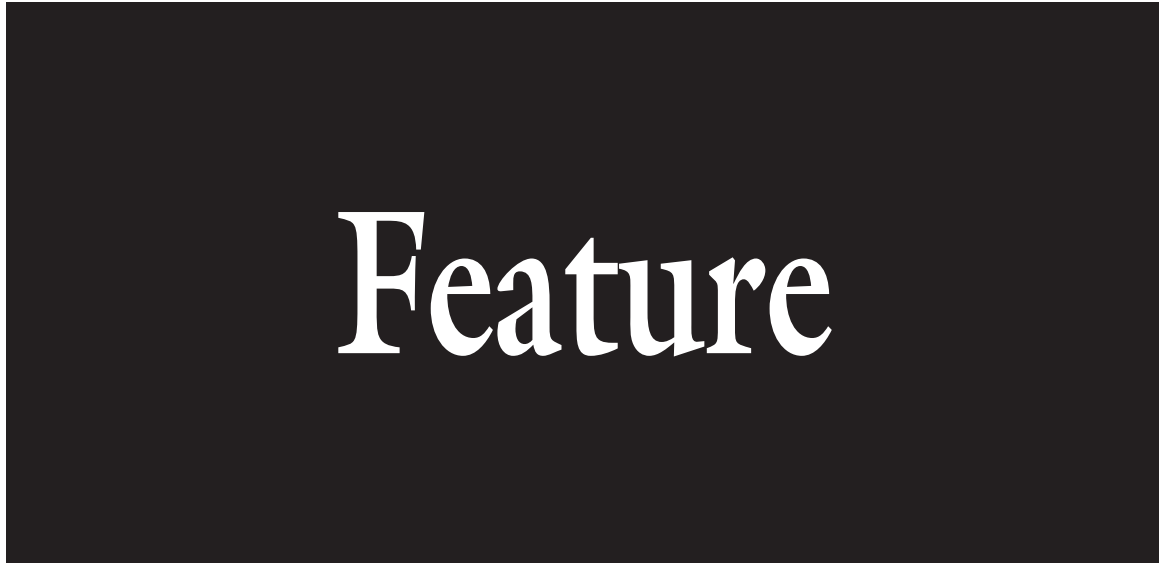

\section{Pecan Leaf Elemental Sufficiency Ranges and Fertilizer Recommendations}

\author{
Michael W. Smith ${ }^{1,4}$, Charles T. Rohla ${ }^{2}$, and William D. Goff ${ }^{3}$
}

AdDitional INDEX words. Carya illinoinensis, native pecan, cultivar pecan, nutrient

Summary. Pecan (Carya illinoinensis) leaf elemental concentrations are the industry standard to guide fertility programs. To provide meaningful information, a standard index tissue collected at a specific development stage is required along with established elemental sufficiency ranges. We report pecan leaf elemental sufficiency ranges used in Oklahoma that were developed based on research in Oklahoma and elsewhere. In addition, fertilizer recommendations, based on various leaf elemental concentrations, are included.

$\mathrm{P}$ lant tissue elemental concentrations are used to assess nutrient availability and guide fertility programs for many fruit crops, including pecan (Bould, 1963; Mills and Jones, 1996; Robinson et al., 1997). In pecan, soil potassium $(\mathrm{K})$, phosphorus $(\mathrm{P})$, and iron $(\mathrm{Fe})$ were not correlated with leaf concentrations and magnesium $(\mathrm{Mg})$ was weakly correlated (Wear and Cope, 1976). Correlation of soil nitrogen $(\mathrm{N})$ with leaf $\mathrm{N}$ concentration was not included in this study. Pecan trees have an extensive root system (Woodroof and Woodroof, 1934) that explores a larger soil volume than can be adequately sampled to estimate nutrient availability.

Approved for publication by the Oklahoma Agricultural Experiment Station.

${ }^{1}$ Regents Professor, Department of Horticulture and Landscape Architecture, Oklahoma State University, Stillwater, OK 74078

${ }^{2}$ Assistant Professor, Samuel Roberts Noble Foundation, Ardmore, OK 73401

${ }^{3}$ Nunn Bond Professor and Extension Horticulturist, Department of Horticulture, Auburn University, Auburn, AL 36849

${ }^{4}$ Corresponding author. E-mail: mike.smith@okstate. edu.
Trees also conserve many nutrients from leaves as they enter dormancy that are used during subsequent years (Acuña-Maldonado et al., 2003; Smith, 2009; Smith et al., 2007)characteristics that can be portrayed by tissue elemental concentrations, but not by soil analysis. Another problem encountered when trying to represent nutrient availability with soil samples is that fertilizers may not be distributed equally over the entire orchard floor. Frequently, producers band or apply the fertilizer to only a portion of the orchard floor, and some nutrients are foliar rather than soil applied. Soil samples are useful to determine if soil $\mathrm{pH}$ adjustment is needed and to assist in diagnosing nutritional problems within the orchard but are inferior to tissue samples for guiding fertility programs.

\section{Index tissue and sample time}

Tissue elemental concentrations must be compared with established sufficiency concentrations to be useful in evaluating plant nutrient status. Since elemental concentrations change throughout the growing season and vary among tissue types (Diver et al., 1984), both the time of year and index tissue must be standardized. Procedures for collecting and handling pecan leaves for elemental concentrations are well established (O'Barr and McBride, 1980) and conveyed to producers by state extension publications and oral presentations at field days. The standard index tissue used for pecan is the middle leaflet pair from the middle leaf on current season's growth (Fig. 1). Typically, $\approx 100$ sunexposed leaflet pairs are collected from several trees representing a uniform area. Elemental concentrations differ between vegetative and fruitbearing shoots (Diver et al., 1984); however, that distinction is not made for producer samples that usually contain a mixture of leaflets from both shoot types. Another caveat when interpreting producer samples vs. samples collected for research purposes is adhering cations from foliar fertilizer applications. Samples supplied for analysis by producers may or may not be washed in tap water. Leaf samples collected for research purposes are usually washed in tap water followed by a P-free detergent solution and then deionized water rinses. If the research includes a foliar-applied nutrient, then a dilute acid solution, typically $0.1 \mathrm{~N}$ hydrochloric acid, is usually included in the washing sequence. Thus, producer samples may appear unusually high in a nutrient that has been applied foliarly. Samples must also be washed soon after

\begin{tabular}{llll}
\hline $\begin{array}{l}\text { Units } \\
\text { To convert U.S. to SI, } \\
\text { multiply by }\end{array}$ & U.S. unit & SI unit & $\begin{array}{l}\text { To convert SI to U.S., } \\
\text { multiply by }\end{array}$ \\
\hline 0.3048 & $\mathrm{ft}$ & $\mathrm{m}$ & 3.2808 \\
2.54 & inch $(\mathrm{es})$ & $\mathrm{cm}$ & 0.3937 \\
0.4536 & $\mathrm{lb}$ & $\mathrm{kg}$ & 2.2046 \\
1.1983 & $\mathrm{~b} / 100 \mathrm{gal}$ & $\mathrm{g} \cdot \mathrm{L}^{-1}$ & 0.8345 \\
1.1209 & $\mathrm{lb} / \mathrm{acre}$ & $\mathrm{kg} \cdot \mathrm{ha}^{-1}$ & 0.8922 \\
1 & $\mathrm{ppm}$ & $\mu \mathrm{g}^{-1}$ & 1 \\
$\left({ }^{\circ} \mathrm{F}-32\right) \div 1.8$ & ${ }^{\circ} \mathrm{F}$ & ${ }^{\circ} \mathrm{C}$ & $\left({ }^{\circ} \mathrm{C} \times 1.8\right)+32$
\end{tabular}

Hortlechnology $\cdot$ October $201222(5)$ 
collection while the leaves are fresh and turgid (Kenworthy, 1967). Nutrileaves are washed when partially dried.

Leaf elemental concentrations change throughout the growing season (Diver et al., 1984), necessitating that the collection time be standardized. To allow a certain degree of flexibility in collection time, a period was

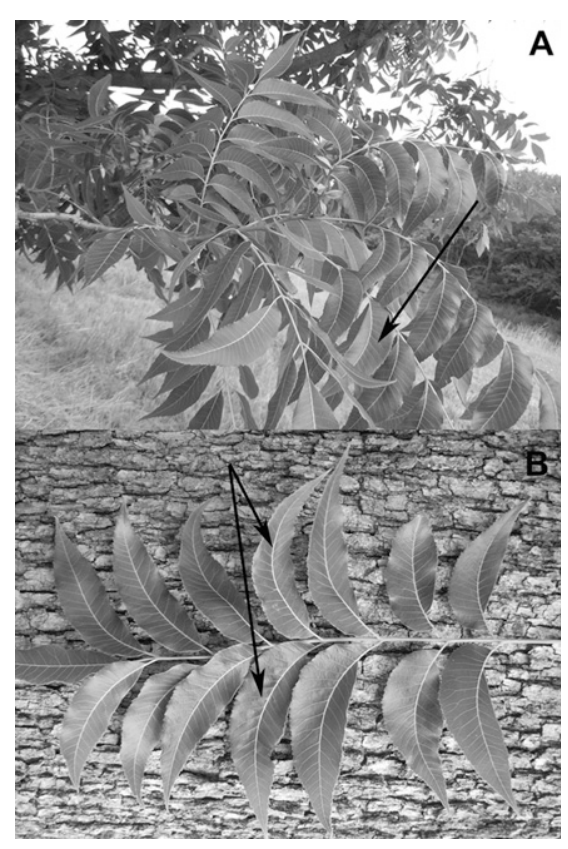

Fig. 1. Pecan index tissue is collected from the (A) middle leaf on a currentseason, sun-exposed shoot (B) using middle leaflet pairs sampled from several trees to represent a uniform area. ent removal, particularly $\mathrm{K}$, is likely if

chosen with the smallest change in elemental composition for an extended period. This period is when shoot extension has ended and leaves from the first growth flush are fully expanded, combined with few nutrient demands by the developing fruit. In Oklahoma, this is the month of July.

\section{Elemental sufficiency ranges}

Pecan leaf elemental sufficiency ranges vary among state extension services; however, there are more similarities than differences in stated sufficiency levels (Jones et al., 1991; Mills and Jones, 1996; Pond et al., 2006; Robinson et al., 1997; Wells, 2009a). Current leaf elemental sufficiency ranges used in Oklahoma for native pecan groves, low-input cultivar orchards, and high-input cultivar orchards are included in Table 1. Differences among states may reflect the tree's tolerance of a relatively wide concentration range for certain elements combined with unique environmental conditions in different geographic regions rather than true differences in the sufficiency range. Kenworthy (1967) made a similar observation when reviewing data for several crops in differing geographic areas stating, "These differences, however, reflect variations in supply rather than physiological requirements." In fact, as research generates more information for specific nutrients, divergence in sufficiency ranges among regions is diminishing.

Table 1. Elemental sufficiency concentration ranges for native orchards, lowinput cultivar orchards, and high-input cultivar pecan orchards using the middle pair of leaflets from the middle leaf on current season's shoots as the index tissue when sampled after the initial spring growth flush and leaves are fully expanded. ${ }^{\mathrm{z}}$

\begin{tabular}{lcc}
\hline & \multicolumn{2}{c}{ Sufficiency concn range } \\
\cline { 2 - 3 } Element $^{\mathrm{y}}$ & $\begin{array}{c}\text { Native orchards and } \\
\text { low-input orchards }\end{array}$ & $\begin{array}{c}\text { High-input } \\
\text { cultivar orchards }\end{array}$ \\
\hline Nitrogen $(\%$ dry weight) & $2.3-3.0$ & $2.4-3.0$ \\
Phosphorus (\% dry weight) & $0.12-0.30$ & $0.14-0.30$ \\
Potassium (\% dry weight) & $0.85-2.50$ & $1.00-2.50$ \\
Sulfur $(\%$ dry weight) & $0.20-0.35$ & $0.20-0.35$ \\
Calcium $(\%$ dry weight $)$ & $0.70-1.75$ & $0.70-1.75$ \\
Magnesium $(\%$ dry weight $)$ & $0.30-0.60$ & $0.30-0.60$ \\
Boron $\left(\mu \mathrm{g} \cdot \mathrm{g}^{-1}\right.$ dry weight $)$ & $15-50$ & $15-50$ \\
Copper $\left(\mu \mathrm{g}^{-1}\right.$ dry weight) & $6-30$ & $6-30$ \\
Iron $\left(\mu \mathrm{g} \cdot \mathrm{g}^{-1}\right.$ dry weight $)$ & $50-300$ & $50-300$ \\
Manganese $\left(\mu \mathrm{g} \cdot \mathrm{g}^{-1}\right.$ dry weight $)$ & $100-2000$ & $100-2000$ \\
Zinc $\left(\mu \mathrm{g} \cdot \mathrm{g}^{-1}\right.$ dry weight) & $60-150$ & $60-150$ \\
Nickel $\left(\mu \mathrm{g} \cdot \mathrm{g}^{-1}\right.$ dry weight $)$ & $>2.5$ & $>2.5$
\end{tabular}

${ }^{2}$ Recommended leaf sample time in Oklahoma is the mo. of July.

${ }^{\mathrm{y}} 1 \mu \mathrm{g} \cdot \mathrm{g}^{-1}=1 \mathrm{ppm}$.
There are recognized differences in production potential among geographic regions that may affect the elemental sufficiency range. Yet, a relatively small amount of each nutrient is invested in the crop. For example, $\mathrm{N}$ is the most frequently deficient and applied nutrient with the greatest abundance in leaves. A common recommendation is to apply $10 \mathrm{lb} /$ acre $\mathrm{N}$ per $100 \mathrm{lb} /$ acre of expected crop (Wells, 2009b), but there is only $\approx 1.3$ $\mathrm{lb}$ of $\mathrm{N}$ in $100 \mathrm{lb}$ of pecans (Smith, 2010). Regional disparity in pecan yields can be up to $1000 \mathrm{lb} /$ acre, but this difference only accounts for 13 $\mathrm{lb} /$ acre $\mathrm{N}$ invested in the crop. Discrepancy in elemental absorption and assimilation exists among various cultivars (Sparks and Madden, 1977; Worley and Mullinix, 1993); however, current resolution to manage such differences is not sufficient, with the possible exception of $\mathrm{N}$ and $\mathrm{K}$ nutrition for 'Desirable' (Wood et al., 2010).

\section{Native groves and low-input cultivar orchards versus high- input cultivar orchards}

Native pecan production is the major portion of pecans produced in Oklahoma, Kansas, and Missouri and an important part of total production in Texas, Arkansas, and Louisiana. Trees in native groves are genetically diverse and randomly spaced with trees of varying age and size intermixed, whereas cultivar orchards usually consist of two to four cultivars with plantings uniform in spacing, age, and tree size (Fig. 2). Sufficiency ranges for $\mathrm{N}, \mathrm{P}$, and $\mathrm{K}$ are lower for native pecan trees and cultivars in low-input management systems than for cultivars in a high-input management system (Table 1). Justification for these discrepancies includes a lower yield potential and less value for nuts from native trees compared with cultivars. In fact, in a native grove most of the production is derived from certain trees while others contribute little (McCraw, 1998), unless judicious records allow removal of unproductive trees when thinning to control crowding. Native groves are typically less responsive to inputs than cultivar orchards because cultivars used today have been selected for a highproduction potential combined with a large kernel percentage. Good quality native pecans in Oklahoma are $\approx 40 \%$ 


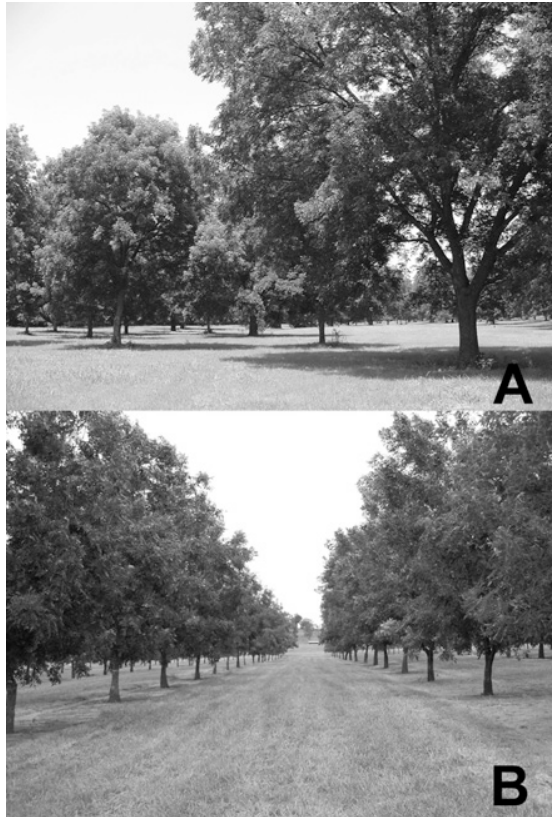

Fig. 2. (A) Native pecan orchard and (B) cultivar pecan orchard.

to $42 \%$ kernel and $90-130$ nuts per pound. Cultivars planted today exceed $50 \%$ kernel with some over $60 \%$ kernel and are at least 70 nuts per pound and some are as large as 40 nuts per pound. Additionally, native groves are not irrigated, whereas highinput cultivar orchards are irrigated, increasing their yield advantage. Since yield potential and nut value are lower for native pecans than cultivars, it is prudent to limit investment for production inputs. In addition, since the target leaf $\mathrm{N}$ concentration is lower for native pecan trees, research has indicated that a lower leaf $\mathrm{K}$ concentration is appropriate (Wells and Wood, 2007).

A similar argument can be made to justify lower standards for lowinput cultivar orchards vs. high-input cultivar orchards. Both orchard types occur throughout Oklahoma, parts of Texas, and the southeast pecan growing region. Low-input cultivar orchards are not irrigated and typically contain less-productive cultivars with a lower shelling percentage than high-input orchards. Additionally, crop load is usually not managed by fruit thinning, foliar and fruit diseases may or may not be controlled, and although arthropod pests are managed in both orchard types, the damage tolerance is greater in low-input orchards. The target market for low-input orchards is shellers rather than the more lucrative early-season, retail and international markets frequented by producers of top-quality nuts from high-input orchards.

\section{Fertilization}

Fertilization guidelines have been developed to attain normal elemental sufficiency ranges based on the leaf elemental concentration for each element. These guidelines are specific for Oklahoma but may be useful in other areas.

\section{Nitrogen (percent dry weight)}

Recommendations for $\mathrm{N}$ adjustment are based on a percentage of the previous year's application. Specific recommendations for the amount to apply are less accurate than basing the recommendations on the previous year's application because of differences in sites, such as groundcover, soil texture, application method, cultural practices, cultivars, and environmental conditions. Certain legume groundcovers are capable of meeting the crops $\mathrm{N}$ needs in some situations (Smith et al., 1996), particularly for native pecan trees and low-input orchards. Recommended specific amounts of $\mathrm{N}$ are for those producers who did not fertilize the previous year or new owners who do not know the orchard's history.

Native Grove, LOW-INPUT CULTIVAR ORCHARDS: $<2.3 \%$-LOW. Double last year's $\mathrm{N}$ application rate. If the orchard did not receive $\mathrm{N}$ last year, apply $150 \mathrm{lb} /$ acre $\mathrm{N}$.

$2.3 \%$ to $2.5 \%$-Normal. Continue present $\mathrm{N}$ application rate.

$2.5 \%$ to $2.7 \%$-Normal. Nitrogen application can be reduced without affecting yield or nut quality. Decrease the application rate by $20 \%$.

$2.7 \%$ to $3.0 \%$-Normal. Nitrogen application can be reduced without affecting yield or nut quality. Decrease the application rate by $50 \%$.

$>3.0 \%$-Above normal. Withhold all $\mathrm{N}$ for one year.

HiGH-INPUT CULTIVAR ORCHARDS: $<2.3 \%$-Very low. Double present $\mathrm{N}$ application rate. If the orchard did not receive $\mathrm{N}$ last year, apply $150 \mathrm{lb} /$ acre $\mathrm{N}$.

$2.3 \%$ to $2.4 \%$-Low. Increase the present $\mathrm{N}$ rate by $30 \%$. If the orchard did not receive $\mathrm{N}$ last year, apply 125 lb/acre $\mathrm{N}$.

$2.4 \%$ to $2.7 \%$-Normal. Continue the present $\mathrm{N}$ application rate.
If none was applied, then none will be needed.

2.7\% to $3.0 \%$-Normal. Nitrogen application can be reduced without affecting yield or nut quality. Decrease application rate by $30 \%$.

$>3.0 \%$-Above normal. Decrease application rate by $50 \%$.

There are several factors to consider when deciding on the best timing, material, and method to apply $\mathrm{N}$ fertilizer. Trees have two high-demand periods, $\approx 3$ weeks after budbreak when $\mathrm{N}$ storage reserves are depleted by the rapidly growing shoots and expanding leaves, and when fruit are beginning the kernel filling process during late summer (Smith et al., 2007). The largest demand period is following depletion of $\mathrm{N}$ storage during spring. Trees absorb $\mathrm{N}$ at other times, but at a slower rate. Therefore, the optimum time to apply $\mathrm{N}$ is during these two periods unless circumstances dictate otherwise. Situations that modify appropriate times to apply $\mathrm{N}$ are rainfall patterns particularly in nonirrigated orchards, groundcover type and management, and type of fertilizer.

Rainfall in Oklahoma tends to be abundant in March through May and then becomes infrequent and less predictable in June through August. In nonirrigated native groves or cultivar orchards, rainfall is vital for incorporation and efficient use of $\mathrm{N}$. Virtually all native pecan groves as well as many cultivar orchards are located in flood plains. Nitrogen can be rapidly lost when soils are flooded or water saturated. Sites that are subject to occasional flooding may benefit from a split $\mathrm{N}$ application with $50 \%$ to $60 \%$ applied before budbreak (typical budbreak in central Oklahoma is $\approx 10$ Apr.) and $40 \%$ to $50 \%$ applied about mid- to late-May. Application later during the season may be poorly used since rainfall may not occur within a reasonable time to incorporate the $\mathrm{N}$ and allow its absorption. Sites with sandy soil may also benefit from a split $\mathrm{N}$ application. A single application applied about budbreak through mid-May is adequate for other sites. Nitrogen application in sprinkler-, microsprinkler-, or floodirrigated orchards is not as closely tied to rainfall patterns for incorporation and utilization allowing $\mathrm{N}$ to be applied just before the highest demand periods.

A split $\mathrm{N}$ application with the first application applied in March 
through mid-May followed by a second application near the completion of the water stage (liquid endosperm) of fruit development (late-July to late-August depending on cultivar and location) has shown mixed results in reducing alternate bearing. If this strategy is employed, a suggested $\mathrm{N}$ distribution is $50 \%$ to $60 \%$ in the spring followed by $40 \%$ to $50 \%$ during the second application. This strategy is best suited for irrigated orchards. Some producers have been successful when $\mathrm{N}$ was only applied near the completion of the fruit water stage.

Orchard groundcover can dramatically modify $\mathrm{N}$ management. Certain legume groundcovers can supply the total $\mathrm{N}$ requirement of native pecan groves and low-input cultivar orchards, and may be capable of meeting the total requirement for highinput cultivar orchards (Smith et al., 1996). However, fertilization of legumes with $\mathrm{N}$ reduces the amount of $\mathrm{N}$ fixed by the legume and tends to reduce the legume stand. In cultivar orchards where vegetation-free strips are maintained with herbicides, distributing applied $\mathrm{N}$ within the vegetationfree zone is an effective method to supplement $\mathrm{N}$ without detracting from the $\mathrm{N}$ supplied by legume groundcover.

Orchard floor groundcovers other than legumes are competitive with trees for available N. Applying N shortly before budbreak appears to favor $\mathrm{N}$ allocation to the tree, especially if the groundcover is composed primarily of warm-season species. Another effective strategy, if available, is to apply $\mathrm{N}$ only in the vegetation-free area of the tree row. Typically, $\mathrm{N}$ rates can be decreased without affecting tree performance and mowing can be reduced.

Urea is the primary source of dry $\mathrm{N}$ fertilizer throughout Oklahoma and in several other areas. Substantial $\mathrm{N}$ loss can result if urea is applied when the temperature exceeds $70{ }^{\circ} \mathrm{F}$ and the soil is wet. At least $1 / 4$ inch of rainfall or irrigation is required to incorporate urea, thus reducing $\mathrm{N}$ loss. Although pecan trees tend to rapidly absorb $\mathrm{N}$ when storage pools are depleted during the initial growth flush, application of urea shortly before budbreak may produce better results than waiting for the period of greatest absorption. Before budbreak, temperatures favor a slower conversion of urea to ammonium $\left(\mathrm{NH}_{4}\right)$ and ammonia $\left(\mathrm{NH}_{3}\right)$; thus, there is less likelihood of $\mathrm{NH}_{3}$ volatilization before reduction of volatile $\mathrm{NH}_{3}$ to soil stable $\mathrm{NH}_{4}$. Additionally, rainfall patterns are favorable to allow incorporation soon after application. Other $\mathrm{N}$ forms used in orchards are not subject to $\mathrm{NH}_{3}$ loss like urea.

Application of liquid $\mathrm{N}$ via a drip or microsprinkler irrigation system may increase $\mathrm{N}$ availability to the tree, thus reducing the amount of $\mathrm{N}$ required to attain the same response (Smith et al., 1979). In certain tree fruit crops, applied $\mathrm{N}$ was reduced by $50 \%$ without affecting leaf $\mathrm{N}$ or yield. Typically, $\mathrm{N}$ is applied through the irrigation system in four equal applications beginning about budbreak and then at 2-week intervals. A split application between March through mid-May followed by application in late-July through late-August (near completion of the fruit water stage), depending on cultivar and location, may be beneficial.

\section{Phosphorus (percent dry weight)}

Native GROVE, LOW-INPUT CULTIVAR ORCHARDS: $<0.12 \%$ - LOW. Apply $100 \mathrm{lb} /$ acre phosphate $\left(\mathrm{P}_{2} \mathrm{O}_{5}\right)$.

$\geq 0.12 \%$ - Normal. None needed.

High-INPUT CULTIVAR ORCHARDS: $<0.14 \%$-Low. Apply $100 \mathrm{lb} /$ acre $\mathrm{P}_{2} \mathrm{O}_{5}$.

$\geq 0.14 \%-$ Normal. None needed. Applying $\mathrm{P}$ as a banded application rather than a broadcast application has been more effective in increasing $\mathrm{P}$ absorption (M.W. Smith, unpublished data). Adjust the spreader to deliver the recommended amount of $\mathrm{P}$ per acre. Apply the P in a band about midway between the trunk and canopy dripline on one side of the tree by leaving the spreader spinners off or blocking their spreading the $\mathrm{P}$, thus applying the $\mathrm{P}$ in a band $\approx 18$ to 24 inches wide on one side of the tree. If the trees are small, apply the band 6 to 8 $\mathrm{ft}$ from the trunk on one side of the tree.

\section{Potassium (percent dry weight)}

Native grove, LOW-INPUT CULTIVAR ORCHARDS: $<0.85 \%$ - LOW. Apply $100 \mathrm{lb} /$ acre potassium oxide $\left(\mathrm{K}_{2} \mathrm{O}\right)$.

$\geq 0.85 \%-$ Normal. None needed.

High-INPUT CULTIVAR ORCHARDS: $<\mathrm{l} .0 \%$-Low. Apply $100 \mathrm{lb} /$ acre $\mathrm{K}_{2} \mathrm{O}$.

$\geq 1.0 \%$ - Normal. None needed.

Applying $\mathrm{K}$ as a banded application rather than a broadcast application has been more effective in increasing $\mathrm{K}$ absorption (M.W. Smith, unpublished data). Adjust the spreader to deliver the recommended amount of $\mathrm{K}$ per acre. Apply the $\mathrm{K}$ in a band about midway between the trunk and canopy dripline on one side of the tree by leaving the spreader spinners off or blocking their spreading the $\mathrm{K}$, thus applying the $\mathrm{K}$ in a band $\approx 18$ to 24 inches wide on one side of the tree. If the trees are small, apply the band 6 to $8 \mathrm{ft}$ from the trunk on one side of the tree. $\mathrm{P}$ and $\mathrm{K}$ can be applied together.

\section{Sulfur (percent dry weight)}

$<0.20 \%$-Low. Sulfur shortage can normally be corrected by using ammonium sulfate for annual $\mathrm{N}$ applications and zinc sulfate $\left(\mathrm{ZnSO}_{4}\right)$ foliar applications for correcting zinc shortage.

$\geq 0.20 \%$-Normal. None needed.

\section{Calcium (percent dry weight)}

$<0.70 \%$ - Low. Apply lime based on soil test information with a target soil $\mathrm{pH}$ of 6.8 .

$\geq 0.70 \%-$ Normal. None needed.

\section{Magnesium (percent dry weight)}

$<0.30 \%$ - Low. Soil test for $\mathrm{pH}$. If low, use dolomitic limestone to adjust soil $\mathrm{pH}$. Otherwise apply magnesium sulfate $\left(\mathrm{MgSO}_{4}\right)$ at the manufacturer's recommendation.

$\geq 0.30 \%$ - Normal. None needed.

\section{Boron (micrograms per gram dry weight)}

$<15 \mu \mathrm{g} \cdot \mathrm{g}^{-1}$-Low. Apply three foliar applications of Solubor (U.S. Borax, Valencia, CA) [20.5\% boron (B)] at 0.5 to $1 \mathrm{lb} /$ acre of material beginning as the first leaf unfurls during budbreak, and then twice more at 2-week intervals. Other commercial B products may be used following the manufacturer's recommendations.

$\geq 15 \mu \mathrm{g} \cdot \mathrm{g}^{-1}-$ Normal. None needed.

$\geq 300 \mu \mathrm{g} \cdot \mathrm{g}^{-1}$-Excess. Boron is water soluble and an excessive leaf concentration is normally from irrigation water. The only correction is a water source with a low B concentration.

In Georgia, foliar B application during prepollination increased fruit retention and kernel percentage of 'Desirable', a cultivar with an exceptional amount of fruit drop, although the trees were not $\mathrm{B}$ deficient (Wells et al., 2008). The range between $\mathrm{B}$ 
sufficiency and toxicity is relatively small and producers should use caution.

\section{Manganese (micrograms per gram dry weight)}

$<100 \mu \mathrm{g} \cdot \mathrm{g}^{-1}$ - Low. Apply three foliar applications of manganese sulfate $\left[\mathrm{MnSO}_{4}(32 \% \mathrm{Mn})\right]$ at $6 \mathrm{lb} /$ acre of material beginning as the first leaf unfurls during budbreak, and then with the first generation pecan nut casebearer spray (late-May to earlyJune), and the second generation pecan nut casebearer spray (late-June to early-July) (Smith et al., 2001). $\mathrm{MnSO}_{4}$ can be tank mixed with $\mathrm{Zn}$ and most pesticides. Other commercial Mn products may be used following the manufacturer's recommendations.

$\geq 100 \mu \mathrm{g} \cdot \mathrm{g}^{-1}$ - Normal. None needed.

\section{Zinc (micrograms per gram dry weight)}

$<60 \mu \mathrm{g} \cdot \mathrm{g}^{-1}$ —Low. Bearing treesapply three foliar applications of $\mathrm{ZnSO}_{4}$ $(36 \% \mathrm{Zn})$ at $6 \mathrm{lb} /$ acre of material beginning as the first leaf unfurls during budbreak, and then with the first generation pecan nut casebearer spray (late-May to early-June) and the second generation pecan nut casebearer spray (late-June to early-July). Highinput cultivar orchards will benefit from an additional $\mathrm{Zn}$ application applied 2 to 3 weeks after the first application. Other $\mathrm{Zn}$ products may be used following the manufacturer's recommendations. If no $\mathrm{Zn}$ has been applied as a foliar application and the leaf $\mathrm{Zn}$ concentration is $\geq 40 \mu \mathrm{g} \cdot \mathrm{g}^{-1}$, then none will be needed. Foliarapplied $\mathrm{Zn}$ results in variable leaf $\mathrm{Zn}$ concentrations because of uneven coverage, necessitating a higher minimum $\mathrm{Zn}$ concentration. When $\mathrm{Zn}$ is root absorbed, leaf $\mathrm{Zn}$ concentrations are more uniform; thus, $40 \mu \mathrm{g} \cdot \mathrm{g}^{-1}$ is adequate (Sparks, 1982).

Nonbearing trees-apply foliar applications of $\mathrm{ZnSO}_{4}(36 \% \mathrm{Zn})$ at 2 $1 \mathrm{~b} / 100$ gal of material in water applied to runoff beginning as the first leaf unfurls during budbreak and then at 2-week intervals until shoot growth ceases. Resume $\mathrm{Zn}$ applications during late-season growth flushes. Other $\mathrm{Zn}$ products may be used following the manufacturer's recommendations.

In drier climates with low humidity, rapid drying of the water droplet reduces $\mathrm{Zn}$ absorption by leaves, necessitating the rates recommended.
In humid climates, water droplets remain on the leaf surface longer, increasing absorption and the potential for leaf damage at rates that are effective in dry climates, thus lower rates $\left(\mathrm{l} \mathrm{lb} / 100 \mathrm{gal}\right.$ of $\mathrm{ZnSO}_{4}$ on nonbearing trees and $\approx 3 \mathrm{lb} /$ acre of $\mathrm{ZnSO}_{4}$ on bearing trees) may be necessary. Producers should adjust the $\mathrm{Zn}$ application rate based on their environmental conditions and leaf elemental analysis. $\geq 60 \mu \mathrm{g} \cdot \mathrm{g}^{-1}$-Normal. Follow current $\mathrm{Zn}$ program.

Soil-applied $\mathrm{ZnSO}_{4}$ was relatively ineffective in supplying the $\mathrm{Zn}$ requirement of pecan trees grown in the high $\mathrm{pH}$, calcareous soils in Texas (Smith et al., 1980). They concluded that in locations where soil conditions render $\mathrm{Zn}$ unavailable, foliar application of $\mathrm{Zn}$ is the best method to satisfy the tree's requirement. In Georgia, on acidic, sandy soil $\mathrm{Zn}$ shortage was successfully corrected on nonbearing pecan trees over four years with a onetime band application of either $\mathrm{ZnSO}_{4}$ or zinc oxide applied within the drip irrigation wetted zone (Wood, 2007).

\section{Iron (micrograms per gram dry weight)}

$<50 \mu \mathrm{g} \cdot \mathrm{g}^{-1}$-Low. Iron deficiency can be induced by cool, wet environmental conditions in the spring that inhibit $\mathrm{Fe}$ translocation from the root system to the aerial portions of the tree (Brown et al., 1959). Improved environmental conditions will permit translocation and the shortage will be eliminated. Corrections of Fe deficiency will normally not be needed unless the shortage persists for two years or the deficiency is acute. If correction is required, use a foliar-applied Fe chelate following the manufacturer's recommendations. Alternatively, a soil application of ethylenediamine$\mathrm{N}, \mathrm{N}^{\prime}$-bis(2-hydroxyphenylacetic acid) [EDDHA] Fe chelate following the manufacturer's recommendation may be effective.

$\geq 50 \mu \mathrm{g} \cdot \mathrm{g}^{-1}-$ Normal, none needed.

\section{Copper (micrograms per gram dry weight)}

$<6 \mu \mathrm{g} \cdot \mathrm{g}^{-1}$-Low. Apply copper sulfate or $\mathrm{Cu}$ chelate at the manufacturer's recommendations.

6 to $20 \mu \mathrm{g} \cdot \mathrm{g}^{-1}$-Normal. None needed.

$>20 \mu \mathrm{g} \cdot \mathrm{g}^{-1}$-Excess. Determine the source of excess $\mathrm{Cu}$.

\section{Nickel (micrograms per gram dry weight)}

$<2.5 \mu \mathrm{g} \cdot \mathrm{g}^{-1}$-Low. The lower threshold for Ni sufficiency has not been firmly established. Trees with less than $2.5 \mu \mathrm{g} \cdot \mathrm{g}^{-1}$ may benefit from $\mathrm{Ni}$ application. Nickel Plus (Nipan, Valdosta, GA) and Nickel CBM (Nipan) are commercially available products for foliar application to correct the problem.

$\geq 2.5 \mu \mathrm{g} \cdot \mathrm{g}^{-1}$-Normal. None needed.

\section{Literature cited}

Acuña-Maldonado, L.E., M.W. Smith, N.O. Maness, B.S. Cheary, B.L. Carroll, and G.V. Johnson. 2003. Influence of nitrogen application time on nitrogen absorption, partitioning, and yield of pecan. J. Amer. Soc. Hort. Sci. 128:155-162.

Bould, C. 1963. Soil and leaf analysis in relation to fruit nutrition. J. Sci. Food Agr. 14:710-718.

Brown, J.C., O.R. Lunt, R.S. Holmes, and L.O. Tiffin. 1959. The bicarbonate ion as an indirect cause of chlorosis. Soil Sci. 88:260-266.

Diver, S.G., M.W. Smith, and R.W. $\mathrm{McNew}$. 1984. Influence of fruit development on seasonal elemental concentrations and distribution in fruit and leaves of pecan. Commun. Soil Sci. Plant Anal. 15:619-637.

Jones, Jr., J.B., B. Wolf, and H.A. Mills. 1991. Plant analysis handbook. MicroMacro Publishing, Athens, GA.

Kenworthy, A.L. 1967. Plant analysis and interpretation of analysis for horticulture crops, p. 59-75. In: M. Stelly (ed.). Soil testing and plant analysis: Part II plant analysis. Soil Sci. Soc. Amer., Madison, WI.

McCraw, D. 1998. Observations on growth and yield of 'Stuart' and native pecan trees in Oklahoma. Proc. Oklahoma Pecan Growers' Assn. 68:18-20.

Mills, H.A. and J.B. Jones, Jr. 1996. Plant analysis handbook II: A practical sampling, preparation, analysis, and interpretation guide. Micro-Macro Publishing, Athens, GA.

O'Barr, R.D. and J.M. McBride. 1980. Pecan leaf sampling for commercial groves. Pecan South 7(3):42-44.

Pond, A.P., J.L. Walworth, M.W. Kilby, R.D. Gibson, R.E. Call, and H. Núñez. 2006. Leaf nutrient levels for pecans. HortScience 41:1339-1341.

Robinson, J.B., M. Treeby, and R.A. Stephenson. 1997. Fruits, vines and nuts, 
p. 347-382. In: D.J. Reuter and J.B. Robinson (eds.). Plant analysis: An interpretation manual. CSIRO Publishing, Collingwood, Victoria, Australia.

Smith, M.W. 2009. Partitioning phosphorus and potassium in pecan trees during high- and low-crop years. J. Amer. Soc. Hort. Sci. 134:399-404.

Smith, M.W. 2010. Relationship of leaf necrosis and defoliation to phosphorus and potassium concentrations in selected tissue and to certain fruit quality parameters of pecan. Scientia Hort. 125:117-122.

Smith, M.W., B.S. Cheary, and B.S. Landgraf. 2001. Manganese deficiency in pecan. HortScience 36:1075-1076.

Smith, M.W., A.L. Kenworthy, and C.L. Bedford. 1979. The response of fruit trees to injection of nitrogen through a trickle irrigation system. J. Amer. Soc. Hort. Sci. 104:311-313.

Smith, M.W., A. Shiferaw, and N.R. Rice. 1996. Legume ground covers as a nitrogen source in pecan. J. Plant Nutr. 19:1117-1130.

Smith, M.W., J.B. Storey, P.N. Westfall, and W.B. Anderson. 1980. Zinc and sulfur content in pecan leaflets as affected by application of sulfur and zinc to calcareous soils. HortScience 15:77-78.

Smith, M.W., B.W. Wood, and W.R. Raun. 2007. Recovery and partitioning of nitrogen from early spring and midsummer applications to pecan trees. J. Amer. Soc. Hort. Sci. 132:758-763.

Sparks, D. 1982. Zinc concentration in pecan leaflets associated with zinc deficiency symptoms. HortScience 17:670671 .

Sparks, D. and G.D. Madden. 1977. Effect of genotype on the elemental concentration of pecan leaves. HortScience $12: 215-252$.

Wear, J.I. and J.T. Cope. 1976. Relationship between soil test values and analysis of pecan leaves taken at three dates. Commun. Soil Sci. Plant Anal. 7:241252.

Wells, M.L. 2009a. Pecan nutrient element status and orchard soil fertility in the southeastern coastal plain of the United States. HortTechnology 19:432-438.
Wells, M.L. 2009b. Top 10 priorities for pecan production. Pecan South 42(5):57,10 .

Wells, M.L., P.J. Conner, J.F. Funderburk, and J.G. Price. 2008. Effects of foliarapplied boron on fruit retention, fruit quality, and tissue boron concentration of pecan. HortScience 43:696-699.

Wells, M.L. and B.W. Wood. 2007. Relationships between leaflet nitrogen: Potassium ratio and yield of pecan. HortTechnology 17:473-479.

Wood, B.W. 2007. Correction of zinc deficiency in pecan by soil banding. HortScience 42:1554-1558.

Wood, B.W., L. Wells, and F. Funderburke. 2010. Influence of elevating tree potassium on fruit drop and yield of pecan. HortScience 45:911-917.

Woodroof, J.G. and N.C. Woodroof. 1934. Pecan root growth and development. J. Agr. Res. 49:511-530.

Worley, R.E. and B. Mullinix. 1993. Nutrient element concentration in leaves for 40 pecan cultivars. Commun. Soil Sci. Plant Anal. 24:2333-2341. 